\title{
Genotoxicity of Drinking Water Disinfectants in Plant Bioassays
}

\author{
Silvano Monarca, ${ }^{1 *}$ Donatella Feretti, ${ }^{2}$ Claudia Zani, ${ }^{2}$ Marco Rizzoni, ${ }^{3}$ \\ Silvia Casarella, ${ }^{3}$ and Bianca Gustavino ${ }^{3}$ \\ ${ }^{1}$ Department of Hygiene and Public Health, University of Perugia, Perugia, Italy \\ ${ }^{2}$ Department of Experimental and Applied Medicine, Hygiene Section, \\ University of Brescia, Brescia, Italy \\ ${ }^{3}$ Department of Biology, University of Rome (Tor Vergata), Rome, Italy
}

\begin{abstract}
The genotoxicity of two widely used drinking water disinfectants, sodium hypochlorite $(\mathrm{NaClO})$ and chlorine dioxide $\left(\mathrm{ClO}_{2}\right)$, and a new disinfectant, peracetic acid ( $\left.\mathrm{PAA}, \mathrm{CH}_{3}-\mathrm{CO}-\mathrm{COOH}\right)$, was evaluated in three short-term plant tests: (1) induction of anaphase chromosome aberrations in the root cells of Allium cepa, (2) micronucleus induction in the root cells of Vicia faba, and (3) micronucleus induction in Tradescantia pollen cells. The study was carried out in the laboratory by directly exposing the plants to several concentrations of the disinfectants in redistilled water at unadjusted (acid) and adjusted (neutral) pHs. Both 0.1 and $0.2 \mathrm{mg} / \mathrm{l} \mathrm{NaClO}$ induced chromosome aberrations in the Allium cepa test at acid $\mathrm{pH}$, but concentrations up to $0.5 \mathrm{mg} / \mathrm{l}$ of all the disinfectants were negative at neutral $\mathrm{pH}$. Concentrations rang-

ing from 0.1 to $0.5 \mathrm{mg} / \mathrm{I} \mathrm{NaClO}, \mathrm{ClO}_{2}$, and PAA induced micronuclei in Vicia faba at acid $\mathrm{pH}$, while 1-2 mg/l NaClO and $\mathrm{ClO}_{2}$ and $0.5-2$ $\mathrm{mg} / \mathrm{l}$ PAA gave positive responses at neutral $\mathrm{pH}$. Most of concentrations of $\mathrm{ClO}_{2}$ produced positive responses in the Tradescantia micronucleus test. In general, the highest levels of genotoxicity were observed under acid conditions; at acid $\mathrm{pH}$, significant effects were induced by low concentrations of $\mathrm{ClO}_{2}$ and PAA. Since the test concentrations of disinfectants are typical of those encountered in the biocidal treatment of tap water and similar concentrations are consumed daily by a large number of people, the genotoxicity of these compounds may constitute a significant public health concern. Environ. Mol. Mutagen. 46:96-103, 2005. (๑) 2005 Wiley-Liss, Inc.
\end{abstract}

Key words: disinfection; drinking water; sodium hypochlorite; chlorine dioxide; peracetic acid; genotoxicity; plant bioassays

\section{INTRODUCTION}

Municipal drinking water is usually supplied by wells or by surface sources (rivers or lakes), which contain varying amounts of natural and anthropogenic organic compounds. Toxic compounds can be formed in finished drinking water by the constituents of the untreated water reacting with disinfectants used for water treatment, especially chlorine. Many of these disinfection by-products (DBPs) have been identified and are known to be mutagenic or carcinogenic in experimental models [WHO, 1996]. Epidemiological studies of populations using chlorinated drinking water obtained from surface sources have demonstrated some evidence for a cancer hazard [Ijsselmuiden et al., 1992; Morris, 1995; Doyle et al., 1997; Koivusalo et al., 1997], in addition to the possibility of spontaneous abortion and other reproductive and developmental effects [Waller et al., 1998; Hwang and Jaakkola, 2003].

Several monitoring studies have detected the presence of mutagenic activity in chlorinated drinking water, using bacterial mutagenicity tests [Alink, 1982; Meier, 1988;
Galassi et al., 1989; Monarca et al., 1998]. The health hazards related to the mutagenicity of drinking water have also been the subject of epidemiological studies in Finland, in the United States, and in Taiwan, where an association between the mutagenicity of chlorinated drinking water and cancer of the urinary and gastrointestinal tract has been found [Koivusalo et al., 1994a,b; Koivusalo et al., 1995; Schenck et al., 1998; Tao et al., 1999].

Drinking water is usually disinfected with the object of not only killing pathogenic microrganisms present in the raw water, but also maintaining small amounts of free disinfectant to prevent acquiring infectious waterborne dis-

*Correspondence to: Silvano Monarca, Department of Hygiene and Public Health, University of Perugia, Via del Giochetto, I-06126 Perugia, Italy. E-mail: monarca@unipg.it

Received 7 July 2004; provisionally accepted 10 September 2004; and in final form 4 February 2005

DOI 10.1002/em.20137

Published online 6 May 2005 in Wiley InterScience (www.interscience. wiley.com). 
ease organisms during water distribution. Therefore, health hazards could result from chronic exposure to these free disinfectant residues. Chlorine, the most commonly used disinfectant, has in fact been found to be carcinogenic [Soffritti et al., 1997], and sodium hypochlorite ( $\mathrm{NaClO})$ [Wlodkowski et al., 1975; Ishidate et al., 1988; Gauthier et al., 1989] and hydrogen peroxide $\left(\mathrm{H}_{2} \mathrm{O}_{2}\right)$ [Ishidate, 1988; Muller and Janz, 1993; Rueff et al., 1993] have displayed mutagenic activity in both in vitro and in vivo short-term tests.

Water samples have been successfully studied with short-term plant tests for chromosomal damage, such as the Allium cepa root anaphase aberration test (Allium cepa test), the Vicia faba root micronucleus (Vicia faba/MN) test, and the Tradescantia micronucleus (Trad/MCN) test. Anaphase aberrations are the first manifestation of the clastogenic/aneugenic effects of a genotoxic compound: anaphase disturbances, such as chromatin bridges, chromosome fragments, and lagging chromosomes, represent the generating events of micronuclei, which appear at the next interphase and arise from the exclusion of genetic material from daughter nuclei. Therefore, both these cytogenetic endpoints give a good measure of genotoxic effects, measuring both clastogenicity and aneugenicity.

Aqueous solutions of single compounds have been evaluated for genotoxicity in the laboratory, using the Trad/MCN test [Mohammed and Ma, 1999; Gong et al., 2003], the Allium cepa test [Ateeq et al., 2002; Rank et al., 2002], and the Vicia faba/MN test [De Marco et al., 1988, 2000]. Besides being useful for studies in the laboratory, these plant systems can be used for field experiments conducted in situ because they do not require concentration or purification of the samples before exposure. In situ studies have used the Trad/MCN test to detect genotoxicants in aquatic systems [Grant et al., 1992], river water [Duan et al., 1999; Jiang et al., 1999], and drinking water [Ma et al., 1985; Helma et al., 1994; Monarca et al., 1998], whereas the Vicia faba test has been employed in assays of river water [Rizzoni et al., 1995; Ji et al., 1999; Miao et al., 1999] and sediments [Rizzoni et al., 1995; Minissi and Lombi, 1997; Minissi et al., 1998]. The anaphase aberration test conducted in Allium cepa root tips has been used to study urban and industrial wastewater [Fiskesjo, 1985; Grover and Satwinderjeet, 1999; Monarca et al., 2000], drinking water [Fiskesjo, 1981], and fresh water [Smaka-Kincl et al., 1996].

Disinfectant-treated surface water samples have been analyzed with these tests to study the genotoxicity associated with DBP formation. In particular, in situ studies have been carried out in river water disinfected continuously in a pilot plant with a new disinfectant, peracetic acid (PAA, $\mathrm{CH}_{3}-\mathrm{CO}-\mathrm{COOH}$ ), using the $\mathrm{Trad} / \mathrm{MCN}$ test [Monarca et al., 2002]. Also, the genotoxicity of lake drinking-water disinfected in a pilot plant with two widely used biocides, chlorine dioxide $\left(\mathrm{ClO}_{2}\right)$ and $\mathrm{NaClO}$, and with PAA has been evaluated using a battery of in vivo and in vitro tests [Mon-
TABLE I. pHs of the Unbuffered Solutions of $\mathrm{NaClO} \mathrm{ClO}_{2}$, and PAA in Redistilled Water Measured Before Plant Exposures

\begin{tabular}{lccc}
\hline & \multicolumn{3}{c}{ Concentrations $(\mathrm{mg} / \mathrm{l})$} \\
\cline { 2 - 4 } Disinfectants & 0.1 & 0.2 & 0.5 \\
\hline $\mathrm{NaClO}$ & 6.2 & 6.0 & 5.6 \\
$\mathrm{ClO}_{2}$ & 6.1 & 5.9 & 5.4 \\
PAA & 6.0 & 5.7 & 5.3 \\
\hline
\end{tabular}

arca et al., 2003, 2004; Buschini et al., 2004a]. The results indicate that the disinfected water is genotoxic in plants, molluscs, and fish. More recently, the genotoxicity specifically associated with the disinfectants was tested in human leukocytes, using the Comet assay, and in Saccharomyces cerevisiae. The three biocides were weakly genotoxic in the first test, although only doses higher than those usually encountered in drinking water were genotoxic in yeast [Buschini et al., 2004b].

The present study is part of an inter-university research program to evaluate and reduce drinking water genotoxicity due to the formation of DBPs and to the presence of free disinfectants in drinking water. In this study, we evaluated the plant genotoxicity specifically associated with the widely used drinking water disinfectants, $\mathrm{ClO}_{2}$ and $\mathrm{NaClO}$. Moreover, we have studied the genotoxicity of the new disinfectant, PAA, up until now used only for wastewater disinfection [Baldry et al., 1995], to examine its applicability for drinking water disinfection. These three disinfectants were tested in redistilled water in the absence of organic compounds and potential precursors of DBPs, using three in situ plant genotoxicity tests: the Allium cepa test, the Vicia faba/MN test, and the Trad/ $\mathrm{MCN}$ test. Because the $\mathrm{pH}$ of treated water varies with the source water, the possible effects of $\mathrm{pH}$ were also studied by comparing the results of plant exposures in buffered and unbuffered disinfectant solutions.

\section{MATERIALS AND METHODS}

\section{Disinfectant Solutions}

A commercial solution of sodium hypochlorite $(14.5-15.5 \% \mathrm{NaClO})$ was obtained from Solvay Chimica Italia SpA (Rosignano, LI, Italy). A chlorine dioxide solution $\left(0.98 \mathrm{~g} \mathrm{ClO}_{2} / \mathrm{l}\right)$ was prepared by passing a stream of $\mathrm{ClO}_{2}$ produced in a generator supplied by Sanipur Srl (Brescia, Italy) through redistilled water. A peracetic acid solution containing $15 \%$ PAA in equilibrium with $15 \% \mathrm{H}_{2} \mathrm{O}_{2}$ was supplied by Promox Srl (Leggiuno, VA, Italy). These disinfectant solutions were diluted in organic-free redistilled water $(\mathrm{pH} \mathrm{5-6)}$ and used at the concentrations specified later. Tests were performed at both unadjusted (acid) and neutral $\mathrm{pH}$. The test solutions were neutralized by adding phosphate buffer solution to the water [APHA, 1998]. Control treatments were performed at the $\mathrm{pHs}$ measured for each test solution. Although all disinfectants acidified the solutions, the pHs of the unbuffered test solutions varied relative to the concentrations of each disinfectant (Table I).

During preliminary experiments, residues of the disinfectants were monitored in the solutions every hour, by colorimetric methods. $\mathrm{NaClO}$ 
TABLE II. Total Anaphase Aberrations and Mitotic Index in Allium cepa Roots Exposed at Neutral and Acid (Unadjusted) $\mathrm{pH}$ to Aqueous Solutions of $\mathrm{NaClO}, \mathrm{ClO}_{2}$, and PAA. Aberrations were Evaluated in 800 Anaphase Cells/Sample and Mitotic Index in 5,000 Cells/Sample

\begin{tabular}{|c|c|c|c|c|}
\hline \multirow[b]{2}{*}{$\begin{array}{l}\text { Disinfectant } \\
(\mathrm{mg} / \mathrm{l})\end{array}$} & \multicolumn{2}{|c|}{ Neutral pH } & \multicolumn{2}{|c|}{ Acid pH } \\
\hline & $\begin{array}{c}\text { Anaphase } \\
\text { aberrations (\%) }\end{array}$ & $\begin{array}{c}\text { Mitotic } \\
\text { index (\%) }\end{array}$ & $\begin{array}{c}\text { Anaphase } \\
\text { aberrations }(\%)\end{array}$ & $\begin{array}{c}\text { Mitotic } \\
\text { index }(\%)\end{array}$ \\
\hline \multicolumn{5}{|l|}{$\mathrm{NaClO}$} \\
\hline 0.1 & 1.4 & 3.7 & $2.6^{*}$ & 6.4 \\
\hline 0.2 & 2.2 & 4.4 & $3.1 * *$ & 4.1 \\
\hline 0.5 & 2.3 & 4.4 & 1.0 & 5.1 \\
\hline Negative control & 1.0 & 4.5 & 0.8 & 5.8 \\
\hline \multicolumn{5}{|l|}{$\mathrm{ClO}_{2}$} \\
\hline 0.1 & 1.9 & 3.7 & 2.8 & 5.1 \\
\hline 0.2 & $2.8^{*}$ & 4.1 & 2.6 & 4.6 \\
\hline 0.5 & 1.1 & 3.7 & 2.2 & 4.5 \\
\hline Negative control & 1.0 & 4.5 & 1.5 & 4.4 \\
\hline \multicolumn{5}{|l|}{ PAA } \\
\hline 0.1 & 1.5 & 5.6 & 2.8 & 5.3 \\
\hline 0.2 & 2.4 & 4.8 & 1.7 & 5.7 \\
\hline 0.5 & 2.4 & 4.6 & 1.7 & 4.4 \\
\hline Negative control & 1.0 & 4.5 & 1.5 & 5.8 \\
\hline
\end{tabular}

$* P<0.05 ; * * P<0.01$ : Statistical significance vs. negative control according to $\chi^{2}$ test.

Positive control: $10 \mathrm{mg} / \mathrm{l}$ maleic hydrazide produced $5.9 \%$ aberrations in anaphase cells and a mitotic index of $2.5 \%$.

concentrations were measured as free dissolved chlorine, using a DR 2000 Hach photometer (Hach Company, Loveland, CO) at $530 \mathrm{~nm}$ (Hach 14070/99 method, adapted from Standard Methods [1998], CI G 4500). $\mathrm{ClO}_{2}$ was determined by the $N, N$-diethyl- $p$-phenylenediamine (DPD) method at $575 \mathrm{~nm}$ (Hach 22423/00 method, adapted from Standard Methods [1998], CI G 4500). For PAA concentrations, water was treated with catalase, followed by potassium iodide, and the concentration of iodine was measured at $530 \mathrm{~nm}$ (Hach 14064/99 method, adapted from Standard Methods, [1998], CI G 4500). PAA calibration curves were obtained by comparing the DPD absorbance of known concentrations of PAA.

Since some reduction in the disinfectant concentrations was found after $2 \mathrm{hr}$ of incubation, the plants were exposed to freshly prepared solutions every $2 \mathrm{hr}$. At the beginning of the plant exposures, each solution was tested for $\mathrm{pH}$. Table I shows the $\mathrm{pH}$ values of the unbuffered (acid) solutions of the three disinfectants measured before plant exposures.

\section{Plant Genotoxicity Tests}

The different plant tests were conducted separately. The three disinfectants were tested together in single Allium cepa and Vicia faba assays. They were also assayed in separate Trad/MCN tests. Each disinfectant was assayed only once in each test.

\section{Allium cepa Root Anaphase Aberration Assay (Allium cepa Test)}

The assay was performed using 10 equal-sized young bulbs per sample of common Allium cepa [Grant, 1982; Fiskesjo, 1988, Rank and Nielsen, 1993]. The test concentrations for each disinfectant were 0.1 , 0.2 , and $0.5 \mathrm{mg} / \mathrm{l}$ at neutral and unadjusted (acid) $\mathrm{pH}$. The bulbs were exposed to these concentrations for $6 \mathrm{hr}$ after a $72 \mathrm{hr}$ pre-germination period in redistilled water. After exposure, the roots were fixed in acetic acid and ethanol (1:3) for $24 \mathrm{hr}$ and stored in $70 \%$ ethanol. One thousand cells per root from five roots (total of 5,000 cells/sample), were scored for mitotic index, as a measure of cellular division. Forty anaphases/root from 20 roots ( 2 roots/bulb) were scored for anaphase aber- rations for a total of 800 anaphasic cells/sample. Anaphase chromosomal aberrations consisted of bridges and fragments, as DNA damage, and of laggards, multipolar anaphases, and c-mitosis, as mitotic spindle damage. Only anaphase/early telophase cells were scored as suggested by Rank and Nielsen [1997]. The results were expressed as the percentage of anaphase aberrations in 800 cells. Redistilled water at both $\mathrm{pH}$ (5.8 and 7.0) was used as the negative control. Ten milligrams per litre of maleic hydrazide was used as the positive control. Data analysis was performed by means of the $\chi^{2}$ test.

\section{Vicia faba Micronucleus Test (Vicia faba/MN Test)}

The micronucleus test was performed in the secondary root tips of Vicia faba according to standard protocols [Degrassi and Rizzoni, 1982]. After germination of the seeds in Hoagland's solution, secondary roots of Vicia faba were exposed in the dark to $0.1,0.2$, and $0.5 \mathrm{mg} / \mathrm{l}$ of the disinfectants in redistilled water. The $\mathrm{pH}$ values of the test agents (see Table I) were then used for untreated control samples, in which root tips were exposed to redistilled water at different acid $\mathrm{pHs}$ (5.2, 5.8, and 6.1), obtained by adding small amounts of $\mathrm{HCl}$ to the water. Buffered solutions $(\mathrm{pH}=7)$ of $0.1,0.2,0.5,1$, and $2 \mathrm{mg} / \mathrm{l}$ of the three disinfectants were also tested. After a 6-hr exposure, the roots were placed in fresh Hoagland's solution and incubated for a further 42 or $66 \mathrm{hr}$. Ten milligrams per litre of maleic hydrazide (6-hr treatment $+42-\mathrm{hr}$ recovery time in Hoagland's solution) was used as the positive control. At the end of the recovery time, secondary roots were removed and fixed in acetic acid and ethanol (1:3). Feulgen staining was performed and the cut tips were squashed onto slides. The mitotic index was estimated from 1,000 cells/tip, and the frequency of micronuclei was determined in $5 \times$ $10^{4}$ cells/sample (mean \pm standard error), by analyzing 5,000 cells/root tip, 2 secondary roots/plant, 5 plants/experimental point (10 root tips/ experimental point, $5 \times 10^{4}$ cells/point). Statistical analysis of the data was carried out by means of the Mann-Whitney test. For comparison between each experimental point and its matched control, each value for treated plants at a particular $\mathrm{pH}$ was compared with the closest $\mathrm{pH}-\mathrm{con}$ trol value with the same fixation time. The Kruskal-Wallis nonparametric 
TABLE III. Types of Anaphase Aberrations Detected in Allium cepa Roots Exposed at Neutral and Acid (Unadjusted) pH to Aqueous Solutions of $\mathrm{NaClO}, \mathrm{ClO}_{2}$, and PAA. Aberrations are Given as the Number Detected in 800 Cells/Sample

\begin{tabular}{|c|c|c|c|c|c|c|c|c|c|c|}
\hline \multirow[b]{3}{*}{$\begin{array}{l}\text { Disinfectant } \\
(\mathrm{mg} / \mathrm{l})\end{array}$} & \multicolumn{5}{|c|}{ Neutral pH } & \multicolumn{5}{|c|}{ Acid $\mathrm{pH}$} \\
\hline & \multicolumn{2}{|c|}{ DNA damage } & \multicolumn{3}{|c|}{ Mitotic spindle damage } & \multicolumn{2}{|c|}{ DNA damage } & \multicolumn{3}{|c|}{ Mitotic spindle damage } \\
\hline & Bridges & Fragments & Laggards & $\begin{array}{c}\text { Multipolar } \\
\text { anaphases }\end{array}$ & c-mitosis & Bridges & Fragments & Laggards & $\begin{array}{c}\text { Multipolar } \\
\text { anaphases }\end{array}$ & c-mitosis \\
\hline \multicolumn{11}{|l|}{$\mathrm{NaClO}$} \\
\hline 0.1 & 4 & 5 & 2 & & & 11 & 3 & 6 & & 1 \\
\hline 0.2 & 11 & 4 & 2 & & & 19 & 3 & 2 & & \\
\hline 0.5 & 7 & 6 & 3 & & & 3 & 1 & 3 & & 1 \\
\hline Negative control & 4 & 3 & 1 & & & 5 & & 1 & & \\
\hline \multicolumn{11}{|l|}{$\mathrm{ClO}_{2}$} \\
\hline 0.1 & 6 & 5 & 4 & & & 10 & 2 & 9 & & 1 \\
\hline 0.2 & 4 & 10 & 7 & 1 & & 19 & 1 & & & \\
\hline 0.5 & 3 & 2 & 4 & & & 7 & 5 & 5 & & \\
\hline Negative control & 4 & 3 & 1 & & & 11 & 1 & & & \\
\hline \multicolumn{11}{|l|}{ PAA } \\
\hline 0.1 & 10 & & 2 & & & 3 & 9 & 8 & & 2 \\
\hline 0.2 & 13 & 3 & 3 & & & 6 & 3 & 3 & & 2 \\
\hline 0.5 & 15 & 2 & 2 & & & 4 & 1 & 7 & & 1 \\
\hline Negative control & 4 & 3 & 1 & & & 5 & 1 & 6 & & \\
\hline
\end{tabular}

ANOVA was used for comparisons among controls with different $\mathrm{pH}$ values at the same fixation time.

\section{Tradescantia Micronucleus Test (Trad/MCN Test)}

The assay was carried out using a hybrid of T. hirsutiflora and T. subacaulis (clone 4430) [Ma et al., 1994]. Inflorescences of the hybrid (15 per sample) were immersed directly in redistilled water containing 0.1 , $0.2,0.5,1,2$, and $10 \mathrm{mg} / \mathrm{l}$ of the disinfectants for 6 or $24 \mathrm{hr}$. An additional set of exposures was conducted with the $\mathrm{pHs}$ adjusted to neutrality. After exposure, the inflorescences were maintained in redistilled water for a further 24 or $6 \mathrm{hr}$ of recovery time, respectively. The buds were then fixed for $24 \mathrm{hr}$ in acetic acid and ethanol (1:3) and stored in $70 \%$ ethanol. Redistilled water (at both $\mathrm{pH} 5.8$ and 7.0) was used as the negative control. Five milligrams per litre of maleic hydrazide was used as a positive control. Slides were prepared from the buds, and the micronucleus frequency in meiotic pollen mother cells was evaluated [Ma et al., 1994]. Over 1,500 tetrads were scored for each sample. The data were expressed as MCN/100 tetrads (mean \pm standard deviation) and analyzed for significance by ANOVA, followed by Dunnett's test for pair-wise comparisons between the redistilled water control and disinfected water groups.

\section{RESULTS}

The results of the Allium cepa tests are shown in Table II-III. Both 0.1 and $0.2 \mathrm{mg} / \mathrm{l} \mathrm{NaClO}$ increased anaphase aberrations, but only at unadjusted (acid) $\mathrm{pH}$. $\mathrm{ClO}_{2}$ was positive only at $0.2 \mathrm{mg} / \mathrm{l}$ at neutral $\mathrm{pH}$, whereas all the test concentrations of PAA were negative at both pHs. The mitotic indices were consistently above $1 \%$, indicating that treatments produced little toxicity and allowed adequate rates of cellular division. The different kinds of aberrations scored are reported in Table III; with one exception, no significant induction in the specific types of DNA, and mitotic spindle damage was detected at either $\mathrm{pH}$ for any of the disin- fectants. Only $0.2 \mathrm{mg} / \mathrm{l} \mathrm{NaClO}$ treatment at unbuffered (acid) $\mathrm{pH}$ produced a statistically significant increase in anaphase aberration induction, according to $\chi^{2}$ test $(P<0.001)$.

Table IV-V show the results of the experiments carried out on Vicia faba. Mitotic indices ranged from 7.2 $\pm 0.9 \%$ to $9.3 \pm 0.3 \%$ (mean \pm standard error) for the treated samples and controls. A statistical analysis of these data (Kruskal-Wallis nonparametric ANOVA) indicated no alterations in the proliferating activity of the roots of the controls and treated groups, at the same $\mathrm{pH}$ (data not shown). Micronucleus frequency was increased significantly by all the disinfectants at both fixation times. Under unbuffered (acid $\mathrm{pH}$ ) conditions, positive responses were found for the entire concentration range tested $(0.1-0.5 \mathrm{mg} / \mathrm{l})$ compared with the controls at the closest $\mathrm{pH}$ value. At the buffered $\mathrm{pH}$, significant increases in micronucleus frequency were detected only at the two highest test concentrations (1 and $2 \mathrm{mg} / \mathrm{l}$ ) of $\mathrm{NaClO}$ and $\mathrm{ClO}_{2}$ and at $0.5-2 \mathrm{mg} / \mathrm{l}$ of PAA. The micronucleus frequencies observed after the 6-hr exposure and 42-hr recovery time were almost always higher than those detected after the 6-hr exposure and 66-hr recovery time. This time-dependent decrease may be due to the progressive dilution of micronuclei during cell proliferation. Analysis of micronucleus induction in control roots indicated that $\mathrm{pH}$ had no significant effect on Vicia faba micronucleus frequency (Table V).

Table VI shows the results of the analyses conducted on the three disinfectants in the Trad/MCN test. $\mathrm{NaClO}$ and PAA were consistently negative at the test concentrations. The longest $\mathrm{NaClO}$ exposure (24-hr followed by $6-$ hr recovery time) induced toxic effects at higher doses, 
TABLE IV. Mean Frequencies $( \pm \mathrm{SE}$ ) of Micronuclei per 1,000 Root Tip Cells of Vicia faba Exposed at Neutral and Unbuffered (acid) $\mathrm{pH}$ to Aqueous Solutions of $\mathrm{NaClO}_{2} \mathrm{ClO}_{2}$, and PAA. Micronuclei were Evaluated in 10 Root Tips, 5,000 Cells/Tip

\begin{tabular}{|c|c|c|c|c|}
\hline \multirow{3}{*}{$\begin{array}{l}\text { Disinfectant } \\
(\mathrm{mg} / \mathrm{l})\end{array}$} & \multicolumn{2}{|c|}{ Neutral pH } & \multicolumn{2}{|c|}{ Acid $\mathrm{pH}^{\mathrm{a}}$} \\
\hline & \multicolumn{2}{|c|}{ Exposure time ( + recovery time) } & \multicolumn{2}{|c|}{ Exposure time ( + recovery time) } \\
\hline & $6(+42) \mathrm{hr}$ & $6(+66) \mathrm{hr}$ & $6(+42) \mathrm{hr}$ & $6(+66) \mathrm{hr}$ \\
\hline \multicolumn{5}{|l|}{$\mathrm{NaClO}$} \\
\hline 0.1 & $0.4 \pm 0.1$ & $0.7 \pm 0.2$ & $1.8 \pm 0.5$ & $1.2 \pm 0.3^{* * *}$ \\
\hline 0.2 & $0.6 \pm 0.1$ & $0.8 \pm 0.2$ & $0.9 \pm 0.1$ & $1.0 \pm 0.2$ \\
\hline 0.5 & $0.5 \pm 0.1$ & $0.8 \pm 0.2$ & $1.7 \pm 0.6^{* * *}$ & $0.8 \pm 0.1 *$ \\
\hline 1.0 & $1.3 \pm 0.2 * *$ & $1.1 \pm 0.1 *$ & - & - \\
\hline 2.0 & $2.2 \pm 0.2 * * *$ & $1.6 \pm 0.2 * * *$ & - & - \\
\hline \multicolumn{5}{|l|}{$\mathrm{ClO}_{2}$} \\
\hline 0.1 & $0.5 \pm 0.1$ & $0.6 \pm 0.2$ & $1.2 \pm 0.2$ & $0.8 \pm 0.2^{* *}$ \\
\hline 0.2 & $0.6 \pm 0.2$ & $0.6 \pm 0.2$ & $2.7 \pm 0.9 * * *$ & $1.4 \pm 0.4^{* * *}$ \\
\hline 0.5 & $0.5 \pm 0.1$ & $0.5 \pm 0.1$ & $4.0 \pm 0.6^{* * *}$ & $1.7 \pm 0.2$ \\
\hline 1.0 & $0.9 \pm 0.1^{*}$ & $0.8 \pm 0.1$ & - & - \\
\hline 2.0 & $1.3 \pm 0.2 * * *$ & $0.8 \pm 0.1$ & - & - \\
\hline \multicolumn{5}{|l|}{ PAA } \\
\hline 0.1 & $0.5 \pm 0.2$ & $0.4 \pm 0.1$ & $0.7 \pm 0.2$ & $0.3 \pm 0.1 * * *$ \\
\hline 0.2 & $0.5 \pm 0.1$ & $0.5 \pm 0.1$ & $0.9 \pm 0.1 * * *$ & $1.1 \pm 0.3^{* * *}$ \\
\hline 0.5 & $1.4 \pm 0.2 * *$ & $0.9 \pm 0.1$ & $5.3 \pm 1.2 * * *$ & $2.6 \pm 0.3$ \\
\hline 1.0 & $1.2 \pm 0.1^{*}$ & $1.0 \pm 0.2$ & - & - \\
\hline 2.0 & $2.0 \pm 0.1^{* * *}$ & $1.6 \pm 0.1 * * *$ & - & - \\
\hline Negative control & $0.3 \pm 0.1$ & $0.4 \pm 0.1$ & see Table V & see Table V \\
\hline
\end{tabular}

- = untested concentration.

Positive control: $10 \mathrm{mg} / \mathrm{l}$ maleic hydrazide produced $7.5 \pm 0.8$ micronuclei per 1,000 cells.

$* P<0.05 ; * * P<0.01 ; * * * P<0.001$.

${ }^{a}$ Statistical significance (Mann-Whitney test) determined vs. acid-pH matched controls (Table V).

TABLE V. Mean Frequencies $( \pm \mathrm{SE})$ of Micronuclei/1,000 Cells of Vicia faba Control Roots Exposed to Redistilled Water at Different Acid pHs, Chosen According to the Values of Unbuffered Disinfectant Solutions. Data Used for Comparisons With Treated Roots (see Table IV)

\begin{tabular}{llc}
\hline & \multicolumn{2}{c}{ Exposure time $(+$ recovery time $)$} \\
\cline { 2 - 3 } $\mathrm{pH}$ & $6(+42) \mathrm{hr}$ & $6(+66) \mathrm{hr}$ \\
\hline 5.2 & $0.6 \pm 0.1$ & $0.6 \pm 0.1$ \\
5.8 & $0.6 \pm 0.1$ & $0.4 \pm 0.1$ \\
6.1 & $0.3 \pm 0.1$ & $0.3 \pm 0.1$ \\
\hline
\end{tabular}

preventing a complete analysis of the test concentrations. For this reason $\mathrm{ClO}_{2}$ and PAA doses of 1, 2, and $10 \mathrm{mg} / \mathrm{l}$ were not evaluated with a 24-hr exposure. $\mathrm{ClO}_{2}(0.2,0.5$, 1 , and $2 \mathrm{mg} / \mathrm{l}$ ) produced positive responses in the Trad/ MCN test, but mainly after the 6-hr exposure under acid (unbuffered) conditions. Under neutral conditions, only the 24-hr exposure to $\mathrm{ClO}_{2}(0.2 \mathrm{mg} / \mathrm{l})$ increased the frequency of micronuclei. The highest concentrations $(10 \mathrm{mg} / \mathrm{l})$ of $\mathrm{NaClO}$ at acid $\mathrm{pH}$ and $\mathrm{ClO}_{2}$ at neutral $\mathrm{pH}$ produced toxicity in the early tetrads.

\section{DISCUSSION}

The results of this study indicate that two widely used drinking water biocides, $\mathrm{NaClO}$ and $\mathrm{ClO}_{2}$, and a new disin- fectant, PAA, have clastogenic/aneugenic activity. In particular, $\mathrm{ClO}_{2}$ showed at least some positive responses in all the plant tests, and some of the positive responses were at concentrations similar to those typically present in tap water. $\mathrm{NaClO}$ was genotoxic in two plant tests, mainly at higher concentrations, and under unbuffered (acid) pH conditions. PAA showed positive responses in only one plant test, and the activity was higher at acid $\mathrm{pH}$.

The three plant tests used to evaluate the disinfectants detect somewhat different genetic endpoints. The Allium cepa test measured the formation of anaphase chromosome aberrations; the tests conducted in Vicia faba and Tradescantia detected DNA damage as micronuclei. These plant tests differed in terms of sensitivity. $\mathrm{NaClO}$ and $\mathrm{ClO}_{2}$ treatments gave positive results with the Allium cepa test only under acid and neutral conditions, respectively, whereas PAA produced no increase in aberrations at either $\mathrm{pH}$. The Vicia faba test was the most sensitive, as it gave positive results with all the disinfectants at most of the test concentrations. This comparative performance among the three plant bioassays confirmed the results found in a previous study on disinfected surface drinking water [Monarca et al., 2003]. Doses as high as $10 \mathrm{mg} / \mathrm{l}$ were used in the Trad/MCN test only with the shorter $(6 \mathrm{hr})$ exposure, because initial experiments indicated that 24-hr exposures resulted in toxic effects at higher doses (data not shown). Only $\mathrm{ClO}_{2}$-treated water 


\begin{tabular}{|c|c|c|c|c|}
\hline \multirow{3}{*}{$\begin{array}{l}\text { Disinfectant } \\
(\mathrm{mg} / \mathrm{l})\end{array}$} & \multicolumn{2}{|c|}{ Neutral pH } & \multicolumn{2}{|c|}{ Acid $\mathrm{pH}$} \\
\hline & \multicolumn{2}{|c|}{ Exposure time (+ recovery time) } & \multicolumn{2}{|c|}{ Exposure time (+ recovery time) } \\
\hline & $6(+24) \mathrm{hr}$ & $24(+6) \mathrm{hr}$ & $6(+24) \mathrm{hr}$ & $24(+6) \mathrm{hr}$ \\
\hline \multicolumn{5}{|l|}{$\mathrm{NaClO}$} \\
\hline 0.1 & $7.0 \pm 3.0$ & $3.3 \pm 1.1$ & $3.5 \pm 1.6$ & $7.1 \pm 0.8$ \\
\hline 0.2 & $6.1 \pm 1.6$ & $4.9 \pm 6.1$ & $3.1 \pm 1.1$ & $6.6 \pm 2.9$ \\
\hline 0.5 & $5.1 \pm 1.1$ & $4.3 \pm 0.8$ & $3.5 \pm 2.2$ & $11.7 \pm 7.6$ \\
\hline 1.0 & $7.0 \pm 4.2$ & - & $4.6 \pm 2.6$ & $7.5 \pm 2.8$ \\
\hline 2.0 & $4.1 \pm 1.1$ & - & $7.4 \pm 6.8$ & $6.6 \pm 2.9$ \\
\hline 10.0 & $7.8 \pm 1.0$ & - & tox & tox \\
\hline Negative control & $4.3 \pm 1.5$ & $4.3 \pm 1.5$ & $6.8 \pm 2.5$ & $6.1 \pm 2.5$ \\
\hline \multicolumn{5}{|l|}{$\mathrm{ClO}_{2}$} \\
\hline 0.1 & $5.0 \pm 4.5$ & $4.9 \pm 3.0$ & $7.5 \pm 4.5$ & $9.3 \pm 6.4$ \\
\hline 0.2 & $3.4 \pm 1.6$ & $6.6 \pm 0.4^{*}$ & $6.4 \pm 2.6^{* *}$ & $4.3 \pm 3.1$ \\
\hline 0.5 & $6.1 \pm 7.2$ & $3.2 \pm 2.3$ & $6.9 \pm 2.3^{* *}$ & $2.8 \pm 1.1$ \\
\hline 1.0 & $5.5 \pm 2.2$ & - & $12.6 \pm 9.9^{*}$ & - \\
\hline 2.0 & $4.7 \pm 2.0$ & - & $6.5 \pm 3.0 * *$ & - \\
\hline 10.0 & tox & - & $4.9 \pm 1.4$ & - \\
\hline Negative control & $4.3 \pm 1.5$ & $4.3 \pm 1.5$ & $2.5 \pm 0.9$ & $2.5 \pm 0.9$ \\
\hline \multicolumn{5}{|l|}{ PAA } \\
\hline 0.1 & $2.3 \pm 0.7$ & $3.5 \pm 2.9$ & $5.5 \pm 6.8$ & $4.7 \pm 2.1$ \\
\hline 0.2 & $2.3 \pm 1.3$ & $7.9 \pm 5.8$ & $11.1 \pm 5.6$ & $5.0 \pm 2.3$ \\
\hline 0.5 & $2.7 \pm 1.0$ & $5.0 \pm 2.5$ & $8.5 \pm 5.9$ & $3.0 \pm 1.4$ \\
\hline 1.0 & $2.3 \pm 1.0$ & - & $4.2 \pm 3.4$ & - \\
\hline 2.0 & $1.8 \pm 0.6$ & - & $11.2 \pm 4.7$ & - \\
\hline 10.0 & $7.3 \pm 3.8$ & - & $16.3 \pm 11.4$ & - \\
\hline Negative control & $4.3 \pm 1.5$ & $4.3 \pm 1.5$ & $3.9 \pm 2.7$ & $3.9 \pm 2.7$ \\
\hline
\end{tabular}

$-\quad=$ untested concentration; tox $=$ toxicity.

Positive control: $5 \mathrm{mg} / 1$ maleic hydrazide produced $15.4 \pm 2.8$ micronuclei/100 tetrads.

${ }^{*} P<0.05 ;{ }^{*} P<<0.01$; statistical significance vs. negative control according to Dunnett's test.

gave positive results in this assay, and mainly under acid conditions. At neutral $\mathrm{pH}, \mathrm{ClO}_{2}$ showed positive results both in the Allium cepa test and the Trad/MCN test at a concentration of $0.2 \mathrm{mg} / \mathrm{l}$, a concentration that is often present in tap water to maintain disinfectant activity during water distribution. These results are consistent with those reported by Buschini et al. [2004b], members of our interuniversity research group, who studied these disinfectants in human leukocytes and Saccharomyces cerevisiae. In the Comet assay, which was more sensitive than the yeast test, all the disinfectants were able to induce genotoxicity: the lowest effective dose for $\mathrm{NaClO}$ and PAA was $0.5 \mathrm{mg} / \mathrm{l}$, whereas for $\mathrm{ClO}_{2}$, it was $0.2 \mathrm{mg} / \mathrm{l}$.

These findings confirm the mutagenicity of $\mathrm{NaClO}$ found by Wlodkowki and Rosenkranz [1975] using the Ames test, and the mutagenicity of $\mathrm{H}_{2} \mathrm{O}_{2}$, present at equilibrium in PAA solutions, found by Rueff et al. [1993]. The genotoxicity of $\mathrm{ClO}_{2}$, first reported by Buschini et al. [2004b], was also confirmed in the present study.

All the disinfectants acidified the treatment solutions to varying degrees. The $\mathrm{pH}$ of the exposure solutions affected the activity of the disinfectants, especially in the Vicia faba test, in which genotoxic activity was found at lower concentrations of all the three disinfectants at unadjusted (acid) $\mathrm{pH}$ than at neutral $\mathrm{pH}$. This did not appear to be due to a direct effect of the acid $\mathrm{pH}$, since $\mathrm{pH}$ had no effect on the responses in the untreated controls. The greater genotoxicity of $\mathrm{NaClO}$ at acid $\mathrm{pH}$ (shown also using Allium cepa) could be due to the higher percentage of undissociated $\mathrm{HClO}$, whereas for PAA it could be due to dissociation products, such as $\mathrm{H}_{2} \mathrm{O}_{2}$. At present, we have no hypotheses as to why this increase occurred for $\mathrm{ClO}_{2}$.

As described in the introduction, the genotoxicity of surface water after treatment with the same disinfectants was recently evaluated in situ by means of the Allium cepa, Vicia faba/MN, and Trad/MCN tests [Monarca et al., 2003]. In that study, concentrations of the free disinfectants were very low $(<0.1 \mathrm{mg} / \mathrm{l})$, and $\mathrm{pH}$ values were close to neutral. Thus, the results of the present study indicate that the genotoxic activity detected in the treated surface water were most likely due to DBPs generated by interactions between organic compounds present 
in the surface water and these disinfectants. $\mathrm{NaClO}$ and $\mathrm{ClO}_{2}$ treatments resulted in the formation of several halogen-containing DBPs, whereas none were observed for PAA-treated water [Monarca et al., 2003].

DBPs were presumably not generated by the disinfectants in redistilled water; therefore, the genotoxic activities detected in this present study may be due to oxidative stress induced by free disinfectants and their dissociation products (e.g., $\mathrm{HClO}$ and $\mathrm{H}_{2} \mathrm{O}_{2}$ ). Although these responses should be confirmed in other systems, the results of this study indicate that plant tests, especially the Vicia faba test, are capable of detecting the genotoxicity of disinfectants, at concentrations typically present in tap water (e.g., $0.1-0.2 \mathrm{mg} / \mathrm{l}$ ). The decrease of genotoxic effects observed under neutral vs. acid $\mathrm{pH}$ conditions should be taken into account when surface disinfected waters are under study, the $\mathrm{pH}$ of which may vary considerably. Since trace amounts of free disinfectants are necessary for preventing waterborne infectious diseases, and are ingested daily by a large number of people, these findings could be relevant to managing human cancer risk.

\section{ACKNOWLEDGMENTS}

This study was supported by the Italian Ministry of Education, University and Scientific Research (MIUR, 2001, S. Monarca, M. Rizzoni).

\section{REFERENCES}

Alink GM. 1982. Genotoxins in waters. In: Sorsa M, Vainio H, editors. Mutagens in our Environment. New York: Alan Liss, Inc. pp 261-276.

APHA. 1998. Standard methods for the examination of water and wastewater. 20th Edition. Washington, DC: American Public Health Association, Inc. pp 5, 58.

Ateeq B, Abul Farah M, Niamat Ali M, Ahmad W. 2002. Clastogenicity of pentachlorophenol, 2,4-D and butachlor evaluated by Allium root tip test. Mutat Res 514:105-113.

Baldry MGC, Cavadore A, French MS, Massa G, Rodrigues LM, Schirch PFT, Threadgold TL. 1995. Effluent disinfection in warm climates with peracetic acid. Water Sci Technol 31:161-164.

Buschini A, Martino A, Gustavino B, Monfrinotti M, Poli P, Rossi C, Santoro M, Dörr AJM, Rizzoni M. 2004a. Comet assay and micronucleus test in circulating erythrocytes of Cyprinus carpio specimens exposed in situ to lake waters treated with disinfectants for potabilization. Mutat Res 557:119-129.

Buschini A, Carboni P, Furlini M, Poli P, Rossi C. 2004b. Sodium hypochlorite-, chlorine dioxide- and peracetic acid-induced genotoxicity detected by the Comet assay and Saccharomyces cerevisiae D7 tests. Mutagenesis 19:157-162.

Degrassi F, Rizzoni M. 1982. Micronucleus test in Vicia faba root tips to detect mutagen damage in fresh-water pollution. Mutat Res 97:19-33.

De Marco A, Paglialunga S, Rizzoni M, Testa A, Trinca S. 1988. Induction of micronuclei in Vicia faba root tips treated with heavy metals in the presence of NTA. Mutat Res 206:311315 .
De Marco A, De Salvia R, Polani S, Ricordy R, Sorrenti F, Perticone P, Cozzi R, D’Ambrosio C, De Simone C, Guidotti M, Albanesi T, Duranti G, Festa F, Gensabella G, Owczarek M. 2000. Evaluation of genotoxic and cytotoxic properties of pesticides employed in Italian agricultural practices. Environ Res 83:311-321.

Doyle TJ, Zheng W, Cerhan JR, Hong CP, Sellers TA, Kushi LH, Folsom AR. 1997. The association of drinking water source and chlorination by-products with cancer incidence among postmenopausal women in Iowa: a prospective cohort study. Am J Public Health 87:1168-1176.

Duan CQ, Hu B, Wang ZH, Wen CH, Yan SQ, Jiang XH, Wang DK, Li Q, Liang XF. 1999. Tradescantia bioassays for the determination of genotoxicity of water in the Panlong River, Kunming, People's Republic of China. Mutat Res 426:127-131.

Fiskesjo G. 1981. Allium test on copper in drinking water. Vatten 37:232-240.

Fiskesjo G. 1985. Allium test on river water from Braån and Saxån before and after closure of a chemical factory. Ambio 14:99-103.

Fiskesjo G. 1988. The Allium test-an alternative in environmental studies: the relative toxicity of metal ions. Mutat Res 197:243-260.

Galassi S, Guzzella L, Sora S. 1989. Mutagenic potential of drinking waters from surface supplies in northern Italy. Environ Toxicol Chem 8:109-116.

Gauthier L, Levi Y, Jaylet A. 1989. Evaluation of the clastogenicity of water treated with sodium hypochlorite or monochloramine using a micronucleus test in newt larvae (Pleurodeles waltl). Mutagenesis 4:170-173.

Gong P, Kuperman RG, Sunahara GI. 2003. Genotoxicity of 2,4- and 2,6-dinitrotoluene as measured by the Tradescantia micronucleus (Trad-MCN) bioassay. Mutat Res 538:13-18.

Grant WF. 1982. Chromosome aberration assay in Allium. A report of the U.S. Environmental Protection Agency Gene-Tox Program. Mutat Res 99:273-291.

Grant WF, Lee HG, Logan DM, Salamone MF. 1992. The use of Tradescantia and Vicia faba bioassays for the in situ detection of mutagens in an aquatic environment. Mutat Res 270:53-64.

Grover IS, Satwinderjeet K. 1999. Genotoxicity of wastewater samples from sewage and industrial effluent detected by the Allium root anaphase aberration and micronucleus assays. Mutat Res 426: 183-188.

Helma C, Sommer R, Schulte-Hermann R, Knasmuller S. 1994. Enhanced clastogenicity of contaminated groundwater following UV irradiation detected by the Tradescantia micronucleus assay. Mutat Res 323:93-98.

Hwang BF, Jaakkola JJ. 2003. Water chlorination and birth defects: a systematic review and meta-analysis. Arch Environ Health 58:83-91.

Ijsselmuiden CB, Gaydos C, Feighner B, Novakoski WL, Servadda D, Caris LH, Vlahov D, Comstock GW. 1992. Cancer of the pancreas and drinking water: a population-based case-control study in Washington County, Maryland. Am J Epidemiol 136:836-842.

Ishidate M, Jr. 1988. A proposed battery of test for the initial evaluation of the mutagenic potential of medicinal and industrial chemicals. Mutat Res 205:397-407.

Ishidate M, Jr., Harnois MC, Sofuni T. 1988. A comparative analysis of data on the clastogenicity of 951 chemical substances tested in mammalian cell cultures. Mutat Res 195:151-213.

Ji Q, Yang H, Zhang X. 1999. Vicia root-micronuclei assays on the clastogenicity of water samples from the Kui River near Xuzhou city, People's Republic of China. Mutat Res 426:133-135.

Jiang YG, Yu ZD, Liu GZ, Chen RZ, Peng GY. 1999. Genetoxicity of water samples from the scenic Lijang river in the Guilin area, China, evaluated by Tradescantia bioassays. Mutat Res 426:137141.

Koivusalo M, Jaakkola JJK, Vartiainen T. 1994a. Drinking water mutagenicity in past exposure assessment of the studies on drinking 
water and cancer: application and evaluation in Finland. Environ Res 64:90-101.

Koivusalo M, Jaakkola JJK, Vartiainen T, Hakulinen T, Karjalainen S, Pukkala E, Tuomisto J. 1994b. Drinking water mutagenicity and gastrointestinal and urinary tract cancers: an ecological study in Finland. Am J Public Health 84:1223-1228.

Koivusalo M, Vartiainen T, Hakulinen T, Pukkala E, Jaakkola JJK. 1995. Drinking water mutagenicity and leukemia, lymphomas, and cancers of the liver, pancreas and soft tissue. Arch Environ Health 50:269-276.

Koivusalo M, Pukkala E, Vartiainen T, Jaakkola JJK, Hakulinen T. 1997. Drinking water chlorination and cancer-A historical cohort study in Finland. Cancer Causes Contr 8:192-200.

Ma TH, Anderson VA, Harris MM, Neas RE, Lee TS. 1985. Mutagenicity of drinking water detected by the Tradescantia micronucleus test. Can J Genet Cytol 27:143-150.

Ma TH, Cabrera GL, Chen R, Gill BS, Sandhu SS, Vandenberg AL, Salamone MF. 1994. Tradescantia micronucleus bioassay. Mutat Res 310:221-230

Meier JR. 1988. Genotoxic activity of organic chemicals in drinking water. Mutat Res 196:211-245.

Miao M, Fu R, Yang D, Zheng L. 1999. Vicia root micronucleus assay on the clastogenicity of water samples from the Xiaoqing River in Shandong Province of the People's Republic of China. Mutat Res 426:143-145.

Minissi S, Lombi E. 1997. Heavy metal content and mutagenic activity, evaluated by Vicia faba micronucleus test of Tiber river sediments. Mutat Res 393:17-21.

Minissi S, Caccese D, Passafiume F, Grella A, Ciccotti E, Rizzoni M. 1998. Mutagenicity (micronucleus test in Vicia faba root tips), polycyclic aromatic hydrocarbons and heavy metal content of sediments collected in Tiber river and its tributaries within the urban area of Rome. Mutat Res 420:77-84.

Mohammed KB, Ma TH. 1999. Tradescantia-micronucleus and stamen hair mutation assays on genotoxicity of the gaseous and liquid forms of pesticides. Mutat Res 426:193-199.

Monarca S, Zanardini A, Feretti D, Dalmiglio A, Falistocco E, Manica P, Nardi G. 1998. Mutagenicity of extracts of lake drinking water treated with different disinfectants in bacterial and plant test. Water Res 32:2689-2695.

Monarca S, Feretti D, Collivignarelli C, Guzzella L, Zerbini I, Bertanza G, Pedrazzani R. 2000. The influence of different disinfectants on mutagenicity and toxicity of urban wastewater. Water Res 34:4261-4269.

Monarca S, Richardson SD, Feretti D, Grottolo M, Thruston AD, Jr., Zani C, Navazio G, Ragazzo P, Zerbini I, Alberti A. 2002. Mutagenicity and disinfection by-products in surface drinking water disinfected with peracetic acid. Environ Toxicol Chem 21:309-318.
Monarca S, Rizzoni M, Gustavino B, Zani C, Feretti D, Zerbini I. 2003. Genotoxicity of surface water treated with different disinfectants using in situ plant tests. Environ Mol Mutagen 41:353-359.

Monarca S, Zani C, Richardson SD, Thruston AD, Jr., Moretti M, Feretti D, Villarini M. 2004. A new approach to evaluate the toxicity and genotoxicity of disinfected drinking water. Water Res 38:3809-3819.

Morris RD. 1995. Drinking water and cancer. Environ Health Perspect 103:225-232.

Muller J, Janz S. 1993. Modulation of the $\mathrm{H}_{2} \mathrm{O}_{2}$-induced SOS response in $E$. coli $\mathrm{PQ} 300$ by amino acids, metal chelators, antioxidants, and scavengers of reactive oxygen species. Environ Mol Mutagen 22:157-163.

Rank J, Nielsen MH. 1993. A modified Allium test as a tool in the screening of the genotoxicity of complex mixtures. Hereditas 118:49-53.

Rank J, Nielsen MH. 1997. Allium cepa anaphase-telophase root tip chromosome aberration assay on $N$-methyl- $N$-nitrosourea, maleic hydrazide, sodium azide, and ethyl methanesulfonate. Mutat Res 390:121-127.

Rank J, Lopez LC, Nielsen MH, Moretton J. 2002. Genotoxicity of maleic hydrazide, acridine and DEHP in Allium cepa root cells performed by two different laboratories. Hereditas 136:13-18.

Rizzoni M, Gustavino B, Ferrari C, Gatti LG, Fano EA. 1995. An integrated approach to the assesment of the environmental quality of the Tiber river in the urban area of Rome: a mutagenesis assay (micronucleus test) and an analysis of macrobenthic community structure. Sci Total Environ 162:127-137.

Rueff J, Bras A, Cristovao L, Mexia J, sa da Costa M, Pires V. 1993. DNA strand breaks and chromosomal aberrations induced by $\mathrm{H}_{2} \mathrm{O}_{2}$ and 60Co gamma-radiation. Mutat Res 289:197-204.

Schenck KM, Wymer LJ, Lykins BW Jr., Clark RM. 1998. Application of a Finnish mutagenicity model to drinking waters in the U.S. Chemosphere 3:451-464.

Smaka-Kincl V, Stegnar P, Lovka M, Toman MJ. 1996. The evaluation of waste, surface and ground water quality using the Allium test procedure. Mutat Res 368:171-179.

Soffritti M, Belpoggi F, Lenzi A, Maltoni C. 1997. Results of long-term carcinogenicity studies of chlorine in rats. Ann N Y Acad Sci 837:189-208.

Tao X, Zhu H, Matanoski GM. 1999. Mutagenic drinking water and risk of male esophageal cancer: a population-based case-control study. Am J Epidemiol 150:443-451.

Waller K, Swan SH, DeLorenze G, Hopkins B. 1998. Trihalomethanes in drinking water and spontaneous abortion. Epidemiology 9:134-140.

Wlodkowski TJ, Rosenkranz HS. 1975. Mutagenicity of sodium hypochlorite for Salmonella typhimurium. Mutat Res 31:39-42.

World Health Organization. 1996. Revision of the WHO guidelines for drinking water quality. Geneva:World Health Organization. 